\title{
Correlation between Principal's Instructional Leadership Practices and Teachers' Organizational Commitment among High Performing Secondary Schools in Anambra State, Nigeria
}

\author{
Abazie Genevive Anulika \\ Ph.D. Candidate, Department of Educational Leadership and Management, Faculty of Education, \\ Southwest University Chongqing, China
}

\begin{abstract}
Nigerian public secondary schools are still grappling with the challenge of poor professional teacher performance. While a growing body of research has identified several factors that explain this poor performance, it has not paid much attention to analyzing whether educational leadership is one of the causes and whether it can provide a solution to this challenge. The aim of this study is to investigate the relationship between the leadership behavior of the school principal and the organizational commitment of teachers in high performing secondary schools in the state of Anambra, Nigeria. The study adopted cross-sectional correlational survey design. The population of the study covered of 6,185 teachers in public secondary schools within the Six Education Zones from Anambra State. Stratified, purposive and simple random sampling techniques were adopted in selecting 448 teaching staff from Twenty Eight (28) public secondary schools within the zone. Using the Principal Instruction Management Rating Scale (PIMRS), the sub-dimensions measured the self-perception of school principals with regard to the frequency of leadership behavior in the classroom in daily management, then self-reports were compared with the reports of the teachers in the schools of the school heads. The data were analyzed by descriptive analysis, data transformation and linear regression. The relationship between educational leadership behavior and organizational commitment was analyzed using the Pearson product. The moment of correlation analysis and the extent to which instruction behavior predicts organizational engagement was examined using multiple linear regression analysis. The results demonstrate educational leadership as a positive and significant predictor of professional performance of teachers. These results suggest that improving educational leadership by providing adequate educational resources for teachers and effectively monitoring and supervising them would advance their proficient performance. Accordingly, the study recommends to the management of Nigeria public secondary schools and Anambra State in particular to stock sufficient teaching resources and to ensure that their principals play their instructional supervisory and monitoring roles effectively.
\end{abstract}

Keywords: Correlation, Principal, Leadership, Teachers, Organizational Commitment, Anambra State. 


\subsection{Introduction}

The purpose of education is to enable citizens to reshape their society and eradicate inequality (Boit et. al (2012). Specifically, secondary education is a significant area in national and individual development, which plays a crucial role in creating a country's human resource base and projects individuals to the level above primary education (Achoka et. al. 2007). One of the indicators of the quality of education offered in secondary education stage is the cognitive performance of students (UNESCO, 2004). According to Adediwura \& Tayo (2007) academic achievement is determined by tests and exam results or grades given by the teachers of the subject; it could also be said to be any term used to represent the academic position or achievement of students.

In order for an individual to perform creditably in secondary education, quality leaders both the principals and class teachers are imperative. Thakur \& Thakur (2004) argued that school leadership is an important determinant of educational quality and academic achievement. Leadership is essential to improve school management and raise education levels. The quality of education depends on the manner in which the school principal is directed, on his ability to control, guide and direct teachers and students. The quality of leadership also plays a critical role in student performance in relation to teachers, students, rules, regulations, and guidelines that govern the school (Buhere, 2007).

Akpan (2015) notes, however, that leadership is the dynamic force that motivates and coordinates the organization to achieve school goals. Pokharel (2015) maintained that they need professional skills to transform, run and manage their schools in order to achieve school effectiveness. Similarly, Abu-Hassain and Essawi (2014) argued that the work of directors is more complex and demanding today than it was in the past. You don't need mediocre leaders presently; rather strong and innovative leaders who are capable of making the desired change in the school system.

Recent policy discussions in the United States, Africa, and other parts of the world suggested widespread support for expanding the involvement of teachers in leadership and decision-making roles in addition to school principals. These discussions are supported by research suggesting that greater teacher involvement in schools has the potential to have significant positive effects on school improvement, including quality performance (Huber, 2004; Leithwood and Beatty, 2007; Leithwood et al., 2008; Matthews \& Sammons, 2005). Studies of 
leadership have focused on school principals while it should be on class teachers. Teachers play a key role in providing quality teaching. Their responsibilities include ensuring the implementation of educational strategies that support effective learning for all students (Wango, 2009). They serve as facilitators, guides, and providers of quality teaching (Bakhda, 2006). Good subject teachers know that good quality teaching is essential to improving student performance.

Nevertheless, Organisations both primary and secondary levels and other learning environments cannot perform to its utmost without the unflinching commitment from its teachers. The Organizational commitment is a perception indicating a sincere adoption of the organization's goals and objectives for the organization to come to a better state by its workers, their efforts and contributions made for this purpose (Ada, Alver and Atl1, 2008). Baysal and Paksoy (1999) argued that organizational engagement involves "the approval and acceptance of the goals, visions and objectives of an organization with great enthusiasm on the part of the worker willing to perform better than expected" the good of the organization". Teachers who work in educational institutions are expected to be more committed to their organizations and tasks and to have a higher professional title. Be more satisfied and motivated than employees in other organizations. The organizational commitment of the teachers is shaped by the attitudes and behavior of their directors. Unsurprisingly, Terzi and Kurt (2005), in their study of teachers' organizational engagement, argued that democratic leadership increases teacher loyalty and teacher engagement is low in schools run by indifferent leaders.

In response to the growing expectations that teachers and principals hold accountable for evidence of increasing student achievement, instructional leadership remains a major focus of education researchers. Given the increasing emphasis on empirical work on distributed leadership models (Spillane, 2006) and the important role of teachers in instructional leadership (Barth, 2001; York-Barr \& Duke, 2004), researchers focused this study on specific instructional leadership behaviors of the primary instructional leader in schools, that's the school principals. According to Hallinger and Murphy (2012), "although effective leadership cannot guarantee successful educational reform, research suggests that sustainable school improvements are seldom found without active and competent teaching by principals and teachers."

In line with this recent and growing emphasis placed upon the role of school building principal to perform as an instructional leader, scholars are interested in exploring and comparing principal self-perceptions of their own instructional leadership behaviors with the perceptions 
held by teachers whose instructional practice these principals supervised. In other words, it is suitable to explore whether or not teachers and principals settled concerning how regularly the principal performs particular behaviors and duties of an instructional leader. The past decades have witnessed the advent of new conceptual models in the field of educational leadership. Two of the most outstanding models, as measured by the number of scholarly works, are instructional leadership and transformational leadership (Heck \& Hallinger, 1999). In contrast to many earlier leadership models applied to school administration (such as situational leadership, trait theories, and contingency theory), these models were concerned explicitly on the manner at which the educational leadership exercised by school administrators and teachers brings about improved educational outcomes (Leithwood \& Jantzi, 1999b; Southworth, 2002).

In their argument, they postulated that instructional leadership process should not only be a process of conveying learned information, but also a process by which people's horizons are broadened far beyond their expectations, giving students a progressive perspective so that they can contribute to the development of civilization, encouraging creative and innovative ideas. During the implementation phase of the educational process, principals who run the process are expected to be effective leaders who adopt an innovative and creative point of view to help the educational system achieve its goals.

On the other hand, Balc1 (1992) argued that effective instruction requires a new administrative perception and a new administrator who runs the school from the classrooms and corridors and who is additionally available if necessary, instead of devoting his time interested in bureaucratic tasks he is committed to pedagogical problems and challenges and is an indispensable part of teaching by guiding teachers, developing teachers' sense of competence and motivating them. While traditional school principals focus on maintenance, repairs, revenue and many other administrative tasks in addition to bureaucratic tasks, teachers attach great importance to the school performance of the students and the teaching process. In this sense, it can be argued that the best leadership approach for schools is the instructional leadership approach (Kurt, 2012).

Scholars like Leithwood (1994) and Whittaker (1997) have tried to link Instructional Leadership to improvement in classroom instructions. Though the term instructional leadership remains an elusive concept, but most of the researchers agree to some extent that principal of schools must be a robust instructional leader. Barth (1990) is quoted in his work as saying, 
"Show me an honest school and I'll show you an honest principal". In light of this statement it's necessary to link instructional leadership perspective with principal's context.

Bridges in his assertion about instructional leadership brought an excessive amount of rethinking on the role of school principal which ultimately cause researches towards a viable model that would be applied broadly to the principals instructional leadership (Barth, 1996; Cuban, 1984). In their remarks, it was argued that "Of the seven major task areas for which principals have responsibility, curriculum and instruction has generated the most sound and fury. On the one hand, the principal has been exhorted to exert instructional leadership; while on the other hand, he has been told flatly that such a role is beyond his or any other human being's capacity. The problem with these disputations is that the exponents of a given position have neither defined sharply what is signified by the concept of instructional leadership nor made their assumptions explicit. (Bridges, 1967)

Many academics, after considering the duties of school principals, compared instructional leadership with transformational leadership (Leithwood, 1994; Leithwood \& Jantzi, 1999, 2000; Silins, 1994), distributed leadership (Gron, 2002; Barth, 1990; Hallinger and Heck , 2010; Marks and Printy, 2003; Pounder, Ogawa and Adams, 1995). The outcome of such results across an enormous number of studies showed fairly consistent patterns of impact, and today, the term 'leadership for learning' has come to incorporate features of instructional leadership, transformational leadership, and shared leadership (Hallinger, 2003; Heck \& Hallinger, 2009; MacBeath \& Cheng, 2008; Marks \& Printy, 2003; Mulford \& Silins, 2009). Zepeda and Sally (2003) described instructional leadership as critical to the event and maintenance of an effective school.

Instructional leaders need to influence others to combine appropriate classroom practices with their best knowledge of the subject. Active teaching of students should be the primary goal, and school principals should provide resources and incentives for teachers to do their best for students. Leithwood (1996) defined six critical dimensions within teaching practice that include: identifying and articulating a vision; promote acceptance of the group's goals; provide individual support; intellectual stimulation; provide a suitable model; and high performance expectations. Hallinger and Murphy (1985) summarized this in their studies when they argued that teaching staff should describe the role of school leaders in three dimensions: defining the school's 
mission, managing the educational program, and promoting a positive school learning environment.

According to Andrews and Soder (1987), an effective school leader as a high level school leader should focus on four areas: the leader should be a resource giver, teaching tool, communicator and visible presence within the school. Though various models on instructional leadership are formulated and studied in western world but there are little or none of any successful models designed keeping into consideration the leadership of principals in African schools, Nigeria in particular. Hence, this study adopts the Hallinger and Murphy model (1985) of instructional leadership by examining the instructional leadership of effective school leaders from southern Nigeria.

\subsection{Statement of the Problem}

Secondary education is the basic requirement for university selection and the development of additional skills (Nwanna, 2017). Bearing in mind that teachers play a major role in the teaching and learning process, there was need to examine the impact of principal's instructional leadership roles of school principals on teacher's organizational commitment. Secondary school students' academic achievement in Nigeria, particularly in Anambra State has been low despite the infrastructural, material and technical support from the government and other stakeholders.

It has been observed that students often fail exams due to inadequate teaching methodology and a lack of commitment of their teachers, reflecting gaps in the director's teaching practice, teachers lacking commitment to duty, funding and institutional management. Findings from the literature show that quality assurance in education is affected by many problems. This miserable achievement worries parents, the government, and the public as they expect good results from students after investing heavily in secondary education.

Research has shown that school leaders who prioritize academics improve student performance (Ankpa, 2018; Cotton, 2014; Short \& Spencer, 1990). In addition, instructional coaching is a promising model for teacher development aimed at improving teaching and learning (Lyons \& Pinnell, 2001; Neufeld \& Roper, 2003; Symonds, 2003). This study therefore sought to analyze the relationship between principal's instructional leadership practices and 
teachers' organizational commitment among high performing public secondary schools in Anambra State of Nigeria.

\subsection{Objectives of the study}

The aim of the current study was to investigate the connection between the instructional leadership practices of the school principal and the organizational commitment of teachers in high-performing secondary schools in the state of Anambra in Nigeria. Specifically, the study aims to:

1. Examine teachers' perception of high-performance leadership behavior in class. Directors of public high schools in the state of Anambra,

2. Examining the organizational engagement of teachers working in these public high schools,

3. Examining whether there is a significant association between teachers' perceptions about the educational leadership behavior of the directors of the public high schools and the organizational engagement of the public high schools teacher and

4. Investigate whether educational leadership is a key predictor of organizational engagement in high performing public high schools in the state of Anambra.

\subsection{Literature Review}

This study is based on a fundamental theory about instructional leadership proposed by Hallinger and Murphy (1985).

\subsection{Instructional Leadership Model by Hallinger and Murphy (1985).}

Numerous notable models of instructional leadership are proposed (Andrews and Soder, 1987; Bossert et al., 1982; Hallinger and Murphy, 1985; Leithwood, Begley and Cousins, 1990; Leithwood and Montgomery, 1982; Van de Grift, 1987; Villanova et al., 1982); During this study, the researcher is interested in the model proposed by Hallinger and Murphy (1985) as it is the model that has been most widely used in empirical research (Hallinger \& Heck, 1996).

Although similar in many ways to the others mentioned above, this model suggests three dimensions for the instructional leadership role of the school principal: defining the school's mission, managing the teaching program, and promoting a positive school learning climate (Hallinger, 2001; Hallinger \& Murphy, 1985a). However, these three dimensions are outlined in 
ten instructional leadership roles. Two of its functions, the design of the school goals and the communication of the school goals, form the primary dimension and define the school's mission. This dimension concerns the principal's role in determining the central purposes of the school or organization. The aspect focuses on the principal's role in working with staff to make sure that the school has clear, measurable, time-based goals focused on the learning progress of students. It's also the principal's responsibility to speak these goals in order that they are widely known and supported throughout the school community.

Within this model, however, the method of goal development was viewed as less critical than the outcome. Goals can be set by the school principal or in collaboration with the staff. The bottom line, however, is that the school must have clear academic goals that the staff supports. This image of academically focused, goal-oriented schools contrasted with the standard situation in which schools were haunted by a vague, ill-defined, and sometimes contradicting set of academic and non-academic goals. The definition of a school mission was captured during a study of California elementary schools by Hallinger and Murphy (1986). During their studies, they observed the teachers in their classrooms for several days. One teacher had an affective education activity center called "I am. .." within the back of the space. However, they never saw students performing at it. When queried about this, the teacher observed: "Yes, the affective activity centers are some of the things I really want to use with my students. However, this particular class did not make standard progress in the core subjects so I had less time for affective activities. Our focus within the school is to ensure that each of our students has mastered core subjects. We actually attempt to make time for optional subjects also. However, our principal expects us to spend as much time as possible reading, writing, spelling, and math as it is important to achieve this goal (emphasis added). So I adjust the time accordingly (Hallinger \& Murphy, 1986)".

Later, in one of his interviews, the director repeated this expectation almost verbatim. Obviously this had been discussed repeatedly with and among the employees. This comment takes up several features of the role of the teacher in defining a transparent mission, such as:

- In this school the mission was perfectly clear; it had been written and visualized in school;

- It had focused on school development appropriate to the needs of this particular school population; 
- The mission is to set a priority of work for teachers in the school;

- The mission had been known and accepted as legitimate by teachers throughout the school, and

- The mission was articulated, actively supported and modeled by the school principal.

The second dimension, Instructional Program Management, focuses on the coordination and control of teaching and curriculum. This dimension encompasses three leadership functions (or what might be called management functions): Monitoring and evaluating teaching, coordinating the curriculum, and monitoring student progress. This dimension requires the principal to be deeply engaged in stimulating, supervising, and monitoring teaching and learning within the school. Obviously, these functions demand that the principal has expertise in teaching and learning, also as a commitment to the school's improvement. It is this dimension that requires the headmaster to be "hip" in the school's curriculum (Bossert et al., 1982; Cuban, 1984; Dwyer, 1986; Edmonds, 1979; Marshall, 1996). Recall the headmaster in the example quoted above. In discussions about monitoring student progress, several different teachers at this school observed that the headmaster "knew the reading level and progress of more than 650 students in this elementary school" (Hallinger \&, 1985b, 1986).

This particular behavior is not a prerequisite for instructional leadership; however, it does reflect the degree of involvement of this school principal in monitoring student progress and managing the school's educational program. The dimension of promoting a positive school learning environment comprises several functions: protecting teaching time, promoting professional development, maintaining high visibility and incentives for teachers, developing high expectations and standards, and creating incentives for learning. This dimension is broader in scope and purpose than the two opposing ones. It is in line with the idea that effective schools create an "academic press" through high standards and expectations of students and teachers (Bossert et al., 1982; Purkey \& Smith, 1983).

Instructionally, effective school leaders develop a culture of continuous improvement in which rewards are aligned with goals and practices (Barth 1990; Glasman 1984; Hallinger and Murphy 1986; Heck et al. 1982; Mortimore, 1993; Purkey \& Smith, 1983). Finally, the school head must model values and practices that create a climate and support the continuous improvement of teaching and learning (Dwyer, 1986; Hallinger \& Murphy, 1985b). 


\subsection{Research Methods}

This study is a cross-sectional correlative study design model, the correlation study is a research model that aims to determine the existence of covariance or its degree of relationship between two or more variables (Karasar, 2015), which is considered relevant to the study aims to examine the relationship between the educational leadership practice of the school principal and the organizational commitment of teachers.

The study population is made up of teachers who work in public secondary schools in the six educational zones of Anambra state. According to the Post Primary Service Commission (2018), the number of teachers was 6,185. A sample of 448 teachers from 28 public secondary schools was selected from the public secondary schools in the zones; Simple, intentional, and stratified random sampling techniques were used; Stratified sampling was used to select schools in their six educational zones. Twenty Eight (28) schools were deliberately selected to represent the total number of schools in each educational zone, while proportional sampling was used to determine the number of teachers in each of the selected schools.

To collect data on the educational leadership behavior of school principals, the researcher administered the Principal Instructional Management Rating Scale (PIMRS) developed by (Hallinger and Murphy, 1985) to the teachers at each school. Six schools in the state of Anambra in Nigeria. Behavior measured by the scale has been defined in the literature as good practice demonstrated by school leaders in effective schools. The survey was carried out electronically by email due to the recent Covid-19 pandemic. The "Organizational Commitment Scale" developed by Balay (2000) was used to collect data on the organizational commitment of teachers.

The questionnaire consists of five dimensions and 50 items. Each of the dimensions comprises 10 five-point Likert scales, which are rated as follows: Set and Share School Goals (PIMRS1); Management of the educational program and the teaching process (PIMRS2); Student and Teaching Process Assessment (PIMRS3); Teacher Support and Development (PIMRS4); Development of a well-organized teaching-learning environment and climate (PIMRS5). The possible answers to the items in the questionnaire were; "(1) Never, (2) Seldom, (3) Sometimes, (4) Often, (5) Always (Şişman, 1997).

Cronbach's alpha reliability coefficients for the sub-dimensions of the questionnaire fluctuated between 0.89 and 0.96 ; the factor analysis showed that the factorial load values of the questionnaire items were between 0.57 and 0.81 . The questionnaire, which had a five-factor 
structure, was $63.3 \%$. This result shows that this questionnaire is valid and reliable (Şişman, 1997).

The scale rates organizational engagement in three dimensions as suggested by O'Reilly and Chatman (1986) for compliance, identification and internalization. The scale comprises of 27 items designed in five-point Likert format and response alternatives are; (1) strongly disagree, (2) little agree, (3) moderately agree, (4) agree and (5) completely agree. There are 8 items in each of the compliance and identification dimensions and 11 items in the internalization dimension (Balay, 2000).

The standard validity of the scale was tested with the factor analysis. To check whether the scale was suitable for the factor analysis, the Kaiser-Meyer-Olkin (KMO) test was carried out and this was set at 0.919. Besides, the result of Bartlett test discovered that the data are suitable for factor analysis $(\mathrm{p}<0.05)$. The items making up the scale were gathered under three factors; the factors loadings of the items varied between 0.49 and 0.85 and the total variance explained was found to be 59.7\%. The Cronbach's alpha reliability coefficients of the sub-dimensions of the scale were found to be $0.73,0.87$ and 0.93 , respectively. These results show that the scale is valid and reliable (Balay, 2000).

The program package SPSS 22.3 was used for the data analysis, it was tested whether the data collected by the data acquisition tools had a normal distribution or not by means of histogram diagrams, asymmetry coefficient values and kurtosis. The skew coefficient was observed to vary between +1 and -1 , the kurtosis coefficient between +3 and -3 , and the data were considered to be normally distributed (Fidell, 1996; cited in Peker, 2015). A normal distribution was used, parametric tests were used. A Pearson (r) product-moment correlation analysis was performed to determine effects such as the direction and magnitude of the relationship between the variables. A multiple linear regression analysis was used to test the extent to which the dimensions of instructional leadership behavior predict the dimensions of organizational commitment. The results of the study analyzes were interpreted at the significance level 0.05, mean, standard deviation values (s) were also used.

\subsection{Result}

In this section, data relating to the correlation between principal's instructional leadership practices and teachers' organizational commitment among high performing secondary schools in Anambra State Nigeria, is analyzed and interpreted according to the sub-objectives of the present 
study. Of 448 questionnaires distributed, 440 were completed and correctly returned. All evaluations were carried out based on the number of items returned.

Table 1: Descriptive statistics showing sub-dimensions of the teachers' perceptions of the instructional leadership behaviors of the principals

\begin{tabular}{|c|c|c|c|c|c|}
\hline $\mathbf{S} / \mathbf{N}$ & Variables & $\mathbf{N}$ & $\mathbf{X}$ & SD & Level \\
\hline 1. & Supporting and improving teachers & 440 & 2.78 & 1.22 & Sometimes \\
\hline 2. & Evaluation of instructional process and students & 440 & 3.22 & 1.17 & Sometimes \\
\hline 3. & $\begin{array}{l}\text { Construction of a well-organized teaching-learning environment } \\
\text { and climate }\end{array}$ & 440 & 3.28 & 1.17 & Sometimes \\
\hline 4. & Management of education program and instructional process & 440 & 3.30 & 1.17 & Sometimes \\
\hline 5. & Setting and sharing of school goals & 440 & 3.43 & 1.09 & Mostly \\
\hline
\end{tabular}

When the data presented in Table 1 were examined in relation to teachers' perceptions of classroom management practices, they clearly showed that school leaders (Principals), showed the most behavior in the dimension of setting and sharing school goals and the least behavior in the supporting and developing dimensions.

Table 2: Descriptive statistics regarding the sub-dimensions of the teachers' organizational commitment levels scale

\begin{tabular}{lcccc}
\hline Sub-Dimensions & $\mathrm{N}$ & $\mathrm{X}$ & $\mathrm{SD}$ & Level \\
\hline Compliance & 440 & 2.03 & 1.20 & Little agree \\
Identification & 440 & 2.75 & 1.23 & Moderately agree \\
Internalization & 440 & 3.22 & 1.14 & Moderately agree \\
\hline
\end{tabular}

Indicative in Table 2, the teachers' commitment at the compliance dimension is low and their level of commitment at the identification and internalization dimensions revealed moderately agree. The results of the correlation analysis are carried out to determine the relationship between principal's instructional leadership practices and teachers' organizational commitment, the result is discussed below in the next table.

Table3: The Results of the bivariate correlation analysis of relationship between the subdimensions of the principal's instructional leadership behavior and organizational commitment. 


\begin{tabular}{|c|c|c|c|c|c|c|c|}
\hline & PIMRS2 & PIMRS3 & PIMRS4 & PIMRS5 & Compl. & Ident. & Intern. \\
\hline PIMRS1 & $.825 * *$ & $.811 * *$ & $.740 * *$ & $.824 * *$ & $-.361 * *$ & $.502 * *$ & $413 * *$ \\
\hline PIMRS2 & & $.852 * *$ & $.778 * *$ & $.815^{* *}$ & $-.315^{* *}$ & $.485 * *$ & $414 * *$ \\
\hline PIMRS3 & & & $.818 * *$ & $.828 * *$ & $-.337 * *$ & $.519 * *$ & $.401 * *$ \\
\hline PIMRS4 & & & & $.825 * *$ & $-.325 * *$ & $.498 * *$ & $.418 * *$ \\
\hline PIMRS5 & & & & & $-.407 * *$ & $.544 * *$ & $.447 * *$ \\
\hline Compl. & & & & & & $-.379 * *$ & $-.265 * *$ \\
\hline Ident. & & & & & & & $.593 * *$ \\
\hline
\end{tabular}

Pearson's correlation coefficients, as shown in Table 3, indicated that all correlation coefficients between dimensions are significant at the 0.05 level. These results postulate that the relationships of principal's instructional leadership behaviors with each other are positive and high and the compliance dimension is negatively correlated with other dimensions of commitment. It turns out that the sub-dimensions of teaching management correlate strongly with one another, but the correlation between the sub-dimensions of organizational commitment is relatively weaker. Here, too, the table showed a negative correlation between the dimensions of adherence to commitment and its other dimensions. The most significant correlation between the pedagogical leadership behavior of the directors and the organizational commitment of the teachers was found for the identification of the respective dimensions, while the least significant correlation was found at the level of the compliance dimension.

Table 4: Multiple regression analysis conducted to elicit the extent to which the sub-dimensions of principals' instructional leadership predict the compliance dimension of organizational commitment

\begin{tabular}{|c|c|c|c|c|c|c|c|}
\hline Variables & $\mathrm{B}$ & Std. Error & $\bar{\beta}$ & $\mathrm{t}$ & Sig. & Zero-order $\mathrm{r}$ & Partial $\mathrm{r}$ \\
\hline Constant & 3.02 & 0.13 & & 22,67 & 0.00 & & \\
\hline PIMRS1 & & -0.10 & 0.07 & -0.13 & -1.46 & 0.15 & -0.361 \\
\hline PIMRS2 & & 0.11 & 0.08 & 0.11 & 1.18 & 0.24 & -0.315 \\
\hline PIMRS3 & & -0.03 & 0.08 & -0.02 & -0.25 & 0.81 & -0.337 \\
\hline PIMRS4 & & 0.02 & 0.06 & 0.03 & 0.36 & 0.72 & -0.325 \\
\hline PIMRS5 & & -0.27 & 0.07 & -0.40 & -4.08 & 0.00 & -0.407 \\
\hline \multicolumn{2}{|l|}{$\mathrm{R}=0.414$} & \multicolumn{3}{|c|}{ Adjusted $\mathrm{R}^{2}=0.162$} & \multicolumn{2}{|c|}{$F(430)=18.00$} & .000 \\
\hline
\end{tabular}


The results shown in Table 4 predict the degree of compliance of the regression mode (compliance $=\mathrm{a}+\mathrm{R} 1 \mathrm{PIMRS} 1+\mathrm{R} 2 \mathrm{PIMRS} 2+\mathrm{R} 3 \mathrm{PIMRS} 3+\mathrm{R} 4 \mathrm{PIMRS} 4+\mathrm{R}$ PIMRS5 + s); and it is found to be statistically significant. The analysis showed that the sub-dimensions of of principal's instructional leadership significantly predict the compliance dimension of organizational commitment $[\mathrm{F}(430)=18.00, \mathrm{p}<0.05]$. The sub-dimensions of instructional leadership explain $17 \%(\mathrm{R} 2=0.171)$ of the total variance in the dimension of adherence to the organizational commitment. Taking into account the $\beta$ values, it was found that the most important of the predictive variables for predicting the compliance dimension is the construction of a well-ordered instructional environment and classroom climate (-0.40). The same dimension was found to be the only significant predictor according to the results of the t-test. Hence, we can predict the linear regression model as follows;

Compliance $=3.02-0.10($ PIMRS1 $)+0.11($ PIMRS2 $)-0.03($ PIRMS3 $)+0.02($ PIRMS4 $)-0.27$ (PIMRS5).

Table 5: Multiple regressions on the prediction of the identification dimension of principal's instructional leadership and organizational commitment

\begin{tabular}{|c|c|c|c|c|c|c|c|}
\hline Variables & $\mathbf{B}$ & Std. Error & $\boldsymbol{\beta}$ & $\mathbf{T}$ & Sig. & $\begin{array}{c}\text { Zero-order } \\
\mathbf{r} \\
\end{array}$ & $\begin{array}{c}\text { Partial } \\
\mathbf{r}\end{array}$ \\
\hline Constant & 0.97 & 0.15 & & 6.38 & 0.00 & & \\
\hline PIMRS1 & 0.11 & 0.08 & 0.10 & 1.28 & 0.20 & 0.502 & 0.061 \\
\hline PIMRS2 & -0.03 & 0.09 & -0.03 & -0.37 & 0.71 & 0.485 & -0.018 \\
\hline PIMRS3 & 0.15 & 0.09 & 0.16 & 1.77 & 0.08 & 0.519 & 0.085 \\
\hline PIMRS4 & 0.07 & 0.07 & 0.07 & 0.96 & 0.34 & 0.498 & 0.046 \\
\hline PIMRS5 & 0.26 & 0.08 & 0.29 & 3.27 & 0.00 & 0.544 & 0.155 \\
\hline $\mathrm{R}=0.561$ & \multicolumn{2}{|c|}{$\mathrm{R}^{2}=0.315$} & \multicolumn{2}{|c|}{ Adjusted $\mathrm{R}^{2}=0.307$} & \multicolumn{2}{|c|}{$\mathrm{F}(430)=40.02$} & 0.000 \\
\hline
\end{tabular}

The regression model used for the prediction in Table 5 shows statistically significant in all sub-dimensions. The results showed that the sub-dimensions of principal's instructional leadership behavior significantly predict the identification dimension of organizational commitment $[\mathrm{F}(430)=40.02, \mathrm{p}<0.05]$. The sub-dimensions of the instructional leadership qualities of the school principal explain $31 \%(\mathrm{R} 2=0.315)$ of the total variance in the dimension 
identification of the organizational commitment of teachers predict that the identification dimension is the construction of a well-organized classroom environment and a well-organized classroom climate $(0.29)$. The same dimension was found to be the only significant predictor according to the t-test results. Hence the linear regression model is interpreted in this way; Identification $=0.97+0.11($ PIMRS1 $)-0.03($ PIMRS2 $)+0.15($ PIMRS3 $)+0.07($ PIMRS4 $)+0.26$ (PIMRS5)

Table 6: Multiple regression analysis results showing the prediction of the internalization dimension of organizational commitment

\begin{tabular}{cccccccc}
\hline Variables & $\mathrm{B}$ & Std. Error & $\beta$ & $\mathrm{T}$ & Sig. & Zero-order r & Partial $\mathrm{r}$ \\
\hline Constant & 1.78 & 0.15 & & 11.56 & 0.00 & & \\
PIMRS1 & 0.09 & 0.08 & 0.09 & 1.05 & 0.29 & 0.413 & 0.050 \\
PIMRS2 & 0.09 & 0.09 & 0.09 & 0.96 & 0.34 & 0.414 & 0.046 \\
PIMRS3 & -0.04 & 0.09 & -0.04 & -0.45 & 0.65 & 0.401 & -0.022 \\
PIMRS4 & 0.11 & 0.07 & 0.12 & 1.49 & 0.14 & 0.418 & 0.071 \\
PIMRS5 & 0.20 & 0.08 & 0.23 & 2.45 & 0.01 & 0.447 & 0.117 \\
\multicolumn{2}{c}{$\mathrm{R}=0.462$} & $\mathrm{R}^{2}=0.213$ & Adjusted $\mathrm{R}^{2}=0.204$ & $\mathrm{~F}(430)=23.55$ & $\mathrm{p}=0.000$ & \\
\hline
\end{tabular}

Multiple regression models in table 6 were used to predict the internalization of the dimensions of teachers organization commitment, the result shows statistically significant in all dimensions. The results indicated that the sub-dimensions of principal's instructional leadership significantly predict the internalization dimension of teachers organizational commitment $[F(430)=23.55, p<0.05]$. The sub-dimensions of instructional leadership qualities of the principal explain $21 \%(\mathrm{R} 2=0.213)$ of the total variance in the internalization dimension of organizational commitment. According to the $\beta$ values, the most important predictive variable for predicting the internalization dimension was the construction of a well-organized classroom environment and classroom climate $(0.23)$. The same dimension was found to be the only significant predictor according to the results of the t-test. Therefore, the linear regression model is expressed as follows;

Internalization $=1.78+0.09($ PIMRS1 $)+0.09($ PIMRS2 $)-0.04($ PIMRS3 $)+0.11($ PIMRS4 $)+$ 0.20 (PIMRS5) 


\subsection{Discussion of Findings}

In light of the results of analyzes conducted on the instructional leadership behavior of school principals and the organizational commitment of teachers in high performing secondary schools in Anambra State, Nigeria, it can be argued that school principals exhibited the most instructional leadership behaviors in relation to the sub-dimensions of goal setting and sharing based on pedagogical leadership, summarized in five dimensions. The dimension that teachers consider school principals to be least suited to, is the sub-dimension of teacher support and development. The leadership behavior of principals in other parts of Africa and of academics around the world has been examined, and many studies (Hallinger, 2005; Gökyer, 2004; Aksoy, 2006; Arın, 2006; Yüce, 2010; Serin, 2011; Şişman, 2012; Recepoğlu and Özdemir, 2013; Sezer, Akan and Ada, 2014; and Kiptum, 2018;) it was argued that teachers felt that the dimension of "setting and sharing school goals" is exploited the most while the dimension of "supporting and developing teachers" is used the least. Thus, the findings as reported from the current study agreed with the findings of other numerous scholars as reported in the body of literature.

Teachers agreed that school principals are able to clearly communicate the school's goals through meetings, seminars and various documents, to evaluate and develop these goals through open discussion in order to improve the performance of teachers and students, and encourage teachers to achieve these goals. The general functioning of the state of Anambra and other states of the Nigerian education system depends to a large extent on administrative efficiency. The goals of the school are set centrally by the stakeholders and the schools function around these given goals. This makes it easier for the directors to stay within the bureaucratic organization to bring teachers together around school goals.

The result of this study showed that teachers felt that the principals exhibit the fewest instructional leadership behaviors in relation to the dimension of supporting and developing teachers. Similar results have been reported by some scholars such as Hallinger (2003), Barth (1990), and Lambert (1998), where they argued that the principal's intention to lead, particularly in secondary schools, is complicated by the fact that in many cases, school principals have less experience than the teachers they supervise. This aspect could not be overcome because the directors do not distance themselves from bureaucratic responsibilities and tendencies and remember that the most important factor in education is the human factor; therefore they need to 
take greater account of teachers' wishes and needs. It is understood, however, that school principals are not good enough to demonstrate educational leadership behavior, such as appreciating the teachers' efforts to encourage and support teachers in their performance, continuing education, informing them about important developments in education and sharing new information and experiences among others. The reason for this negative perception could be that school principals spend most of their time on bureaucratic tasks and stick to standard procedures for completing their duties.

However, the teachers' responses to the items on the organizational commitment scale generally do not correlate the items on the compliance dimension. According to Başaran (1996), compliance behavior is the result of the worker's efforts to strike a balance in the individual's interaction with the environment and generally leads to compliance with authorities, rules and procedures. Since this is beneficial for those responsible, it is generally seen as a means of finding short-term emergency solutions (Balay, 2000a, 96). This finding is analogous to the findings of Balay (2000a).

Again, this study discovered that the teachers' organizational commitment perceptions related to identification commitment are at moderate level of agreement. Identification commitment occurs in the form of establishing satisfactory relationships with others or maintaining such relationships and in this way, the individual is proud of being a member of a group (Dogan and K1lic, 2007). This finding posits that the teacher demonstrate commitment to their institutions at a level lower than the required and can not establish as a satisfactory relationship with their institutions as they wish. As the teachers think that they are not supported to reach and share new information about their profession, they become hesitant about exhibiting their talents. In this case, teachers only execute the performance expected from them and are not willing to exhibit a better performance than required.

The findings of the current study, similar to the findings of other studies ( Hallinger and Murphy, 1985, Hallinger, 2005, Balay, 2000a; Buluç, 2009; Yüce, 2010; Okcu, 2011), who argued that the teachers' perceptions related to the internalization dimension of organizational commitment are higher than those of the other dimensions. However, even at this dimension, they are considered to be at the moderate agree level. As the internalization dimension occurs as a result of a match between organizational and individual values, it can be argued that the teachers are in a moderate compliance with the goals and values of the school. However, the 
quality of education in school organization improves depending on the extent to which teachers internalize the values of the organization. Concisely, it is said that the teachers' organizational commitment at the compliance dimension was found to be low and moderately agree level at identification and internalization dimensions. In order to increase teachers' commitment to their organization, there is need for instructional leaders who do not strictly adhere to administrative procedures, more support teacher development, have strong communications skills, inspire trust and attach great importance to inter-groups communication.

The results of the correlation analysis carried out to determine the relationship between the sub-dimensions of principal's instructional leadership and the sub-dimensions of teacher's organizational commitment in high performing schools showed that there is a negative correlation between the sub-dimensions of instructional leadership and the compliance dimension of organizational commitment, while there is a positive correlation between the subdimensions of principal's instructional leadership, identification and internalization dimensions. A positive and medium-level correlation was established among all the dimensions of principal's instructional leadership and identification and internalization sub-dimensions of teacher's organizational commitment. The results of the multiple regression analysis showed that the best predictor of organizational commitment is the "construction of a well-organized learningteaching environment and climate" sub-dimension of principal's instructional leadership. This dimension predicts teachers' organizational commitment at the compliance dimension by $17 \%$, at the identification dimension by $31 \%$ and at the internalization dimension by $21 \%$. The conclusion reached by Hallinger, (2005); Serin and Buluç (2012) concur that as a whole, principals instructional leadership behaviors are a predictor of teachers' organizational commitment which is analogous to the finding of the current body of study.

\subsection{Conclusion and Recommendations}

The results of the study showed that there is a significant correlation between the educational leadership behavior of the school principal and the organizational commitment of the teachers, which is inevitably reflected in the academic performance of the students in their academic work. A strong association existed between instructional leadership and students' academic achievement and that an outstanding leadership was a key characteristic of schools that perform well in examinations. The instructional leadership is critical for curriculum 
implementation, evaluation and supervision aspects that lead to higher students' academic performances. In order to improve learning and students' achievement, focus should be on the development of qualified and experienced teachers with strong principal's instructional leadership abilities.

From the results of the study, the researcher recommends that principals' instructional leadership should be improved by introducing instructional leadership training sessions for school principals. The teachers can also be encouraged and provided with financial support to attend instructional leadership workshops, seminars and conferences. School administration should also create an environment conducive for the growth of instructional leadership. Teachers should be encouraged to continuously acquire instructional leadership skills within and outside school systems through training, workshops and seminars.

Finally, efforts should be made by or put forth by principals to organize social activities that will promote the interaction with teachers, students and other personnel, to lessen the financial requirements for instructional activities and to obtain the support of parents and other stakeholders for the success of the school; this will increase teachers' organizational commitment.

\section{References}

Abu-Hussian \& Essawi, M. (2014). Value orientation and leadership styles among school principals in Israeli's Arap education system. International Journal of Business administration, 5(3), 49-58.

Achoka, J. S. K., Odebero, S., Maiyo, J. K. \& Mualuko, N. J. (2007). Access to Basic Education in Kenya: Inherent Concerns. Educational Research and Review, 2 (10): 275-284.

Ada, N., Alver, İ, Atl1, F. (2008). The Effect of Organizational Communication on Organizational Commitment, Ege Academic View Journal, 8 (2), 487-518.

Adediwura, A. A. \& Tayo, T. (2007).Perceptions of Teacher Knowledge, Attitude and Teaching Skills as Predictor of Academic Performance in Nigerian Secondary Schools. Educational Research and Review, 2(7): 165-17.

Akpan, C. P. (2015). Work-related variables as correlates of institutional commitment of secondary school teachers in Cross River State, Nigeria. Mediterranean Journal of Social Sciences. 6(3), 315-325.

Aksoy, E. (2006). Instructional Leadership Roles of Primary School Administrators, Unpublished Master's Thesis, Institute of Social Sciences, Çanakkale Onsekiz Mart University.

Ankpa, B.C. (2018). Let me entertain you: the ambivalent role of university lecturers as educators and performers, Educational Review, 71(2), 218-233. 
Arın, A. (2006). The Relationship Between High School Managers' Instructional Leadership Behaviors and Their Decision Making Strategies and Problem Solving Skills. Osmangazi University, Unpublished Master's Thesis, Eskişehir, Turkey.

Backdha, P. (2006). Staff development programmes and academic staff performance of universities in Uganda: A case of Kyambogo University, Uganda (Masters Dissertation, Kyambogo University).

Balay, R. (2000). Organizational Commitment in Managers and Teachers, Ankara: Nobel Publications.

Balay, R. (2000a). Organizational Commitment of Administrators and Teachers in Private and Public High Schools. Unpublished Doctoral Dissertation, Institute of Social Sciences, Ankara University.

Balc1, A. (1992). İlköğretimde Öğretimin Niteliğinin Geliştirilmesi, Hacettepe University Ĕgitim Fakültesi Dergisi, 8: 157-166.

Barth, R. (1990) Improving Schools from Within (San Francisco, CA, Jossey-Bass).

Barth, R. (2001). Teacher leader. Phi Delta Kappan, 82(6), 443-449.

Basaran, İ. E. (1996). Education System Turkey, Ankara: Rose Publications.

Boit, M., Njoki, A. \& Chang'ach, J. K. (2012). The Influence of Examinations on the Stated Curriculum Goals. American International Journal of Contemporary Research, 2(2), 179 $-182$

Bossert, S., Dwyer, D., Rowan, B., \& Lee, G. (1982). The instructional management role of the principal. Educational Administration Quarterly, 18(3), 34-64.

Bridges, E. (1967). Instructional leadership: A concept reexamined. Journal of Educational Administration, 5(2), 136-147.

Buhere, P., (2007). A study of Quality of Education in Public Secondary Schools in Bungoma Division of Bungoma District. Unpublished MED Project, University of Nairobi.

Cotton, L. (2014). Introduction justifying a cross-cultural comparative approach to school leadership and management. School Leadership and Management, 20(2), 137-141.

Cuban, L. (1984). Transforming the frog into a prince: Effective schools research, policy, and practice at the district level. Harvard Educational Review, 54(2), 129-151.

Cuban, L. (1984). Transforming the frog into a prince: Effective schools research, policy, and practice at the district level. Harvard Educational Review, 54(2), 128-151.

Dogan, S. and Kilic, S. (2007). The Place and Importance of Empowerment in Ensuring Organizational Commitment. Erciyes University Faculty of Economics and Administrative Sciences Journal, 29, 37-61.

Dwyer, D. (1986). Understanding the principal's contribution to instruction. Peabody Journal of Education, 63(1), 3-18.

Edmonds, R. (1979). Effective schools for the urban poor. Educational Leadership, 37, 15-24.

Fidel, H. (1996). The relationship between transformational and transactional leadership and school improvement outcomes. School Effectiveness and School Improvement, 5(3) 272298.

Glasman, N. (1984). Student achievement and the school principal. Educational Evaluation and Policy Analysis, 6(3), 283-296.

Göker, N. (2004). The Levels of Primary School Principals' Performing Instructional Leadership Roles and the Factors Limiting These Roles. Unpublished Doctoral Dissertation, Institute of Social Sciences, Hacettepe University, Ankara, Turkey. 
Gronn, P. (2003). The new work of educational leaders: Changing leadership practice in an era of school reform. London: Sage Publications.

Hallinger, P. \& Murphy, J. (1985). Assessing instructional leadership behavior of principals. Elementary School Journal, 86(2), 217-248.

Hallinger, P. (2001). Conceptual models, methodology, and methods for studying school leadership. In J., Murphy, \& K., Seashore-Louis (Eds.), The 2nd handbook of research in educational administration. San Francisco: McCutchan.

Hallinger, P. (2003) School leadership development: global challenges and opportunities, in: P.

Hallinger, P. (2003) Two decades of ferment in school leadership development in retrospect: 1980-2000, in: P. HALLINGER (Ed.) Reshaping the Landscape of School Leadership Development: a global perspective (Lisse, Netherlands, Swets \& Zeitlinger).

Hallinger, P. (2003). Leading educational change: Reflections on the practice of instructional and transformational leadership. Cambridge Journal of Education, 33(3), 329-352.

Hallinger, P. (2008). School leader development: Current trends from a global perspective. In P., Hallinger (Ed.), Reshaping the landscape of school leadership development: A global perspective. Lisse, Netherlands: Swets \& Zeitlinger..

Hallinger, P., \& Heck, R. (1996b). The principal's role in school effectiveness: A review of methodological issues, 1980-95. In K., Leithwood, et al. (Ed.), The international handbook of educational leadership and administration (pp. 723-784). Dordrecht, Netherlands: Kluwer.

Hallinger, P., \& Heck, R. (2002). What do you call people with visions? The role of vision, mission and goals in school improvement. In K., Leithwood, et al, (Eds.), The second international handbook of educational leadership and administration. Dordrecht, The Netherlands: Kluwer.

Hallinger, P., \& Heck, R. (2005). What do you call people with visions? The role of vision, mission and goals in school improvement. In K., Leithwood, et al, (Eds.), The second international handbook of educational leadership and administration. Dordrecht, The Netherlands: Kluwer.

Hallinger, P., \& Heck, R.H. (2010). Collaborative leadership and school improvement: Understanding the impact on school capacity and student learning. School Leadership and Management.

Hallinger, P., \& Murphy, J. (1985). Assessing the instructional leadership behaviour of principals. Elementary School Journal, 86(2), 217-248.

Hallinger, P., \& Murphy, J. (1985a). Assessing the instructional leadership behavior of principals. Elementary School Journal, 86(2), 217-248.

Hallinger, P., \& Murphy, J. (1985b). What's effective for whom? School context and student achievement. Planning and Changing, 16(3), 152-160.

Hallinger, P., \& Murphy, J. (1986). The social context of effective schools. American Journal of Education, 94(3), 328-355.

Hallinger, P., \& Murphy, J. (2012). Running on empty? Finding the time and capacity to lead learning. NASSP Bulletin, 97(1), 5-21.

Huber (2004). Developing leaders for self-managing schools: The role of a principal center in accreditation and professional learning. In P., Hallinger (Ed.), Reshaping the landscape of school leadership development: A global perspective. Lisse, Netherlands: Swets \& Zeitlinger. 
Karasar, S. F., (2015). Leadership, not magic. Educational Leadership, 68(4), 28-33. Retrieved from www.ascd.org.

Kiptum, C. (2018). Correlation between instructional leadership and students' academic achievement in public secondary schools in Baringo County, Kenya. British Journal of Education;6,(1):92-102. www.eajournals.org

Kurt, T. (2012). Okul Yönetiminde İnsan İlişkileri. In (Editor: Servet Özdemir) Türk Egitim Sistemi ve Okul Yönetimi, 4th Edition Ankara: Nobel Publications.

Lambert, L. (1998) Building Leadership Capacity in Schools (Alexandria, VA, Association for Supervision and Curriculum Development).

Leithwood, C., Harris, A., \& Hadfield, M. 2008). Challenging the orthodoxy of effective school leadership. International Journal of Leadership in Education, 4(1), 39-56.

Leithwood, K. \& Jantzi, D. (1999). The relative effects of principal and teachers sources of leadership on student engagement with school. Educational Administration Quarterly, $35,679-706$.

Leithwood, K. (1994). Leadership for school restructuring. Educational Administration Quarterly, 30(4), 498-518.

Leithwood, K., \& Beatty, B. (2007). Leading with teacher emotions in mind. Thousand Oaks, CA: Corwin.

Leithwood, K., \& Montgomery, D. (1982). The role of the elementary principal in program improvement. Review of Educational Research, 52(3), 309-339.

Leithwood, K., Begley, P., \& Cousins, B. (1990). The nature, causes and consequences of principals' practices: An agenda for future research. Journal of Educational Administration, 28(4), 5-31.

Lyon, R \& Pinne, G. A. (2001). Organizational Behaviour in Education,Allyn \& Bacon

MacBeath, J., \& Cheng, Y.C. (2008). Leadership for learning: International perspectives. Rotterdam: Sense Publishers.

Marks, H., \& Printy, S. (2003). Principal leadership and school performance: An integration of transformational and instructional leadership. Educational Administration Quarterly, 39(3), 370-397.

Marshall, K (1996). How I confronted HSPS (Hyperactive Superficial Principal Syndrome). Phi Delta Kappan, 77(5), 336-345.

Mattew, E.T. \& Sammons , L.M. (2005). Classroom management: A critical part of educational psychology with implications for teacher education. Educational Psychologist, Vol. 36, 103-112.

Mortimore, P. (1993). School effectiveness and the management of effective learning and teaching. School Effectiveness and School Improvement, 4, 290-310.

Mulford, B., \& Silins, H. (2009). Revised models and conceptualization of successful school principalship in Tasmania. In B. Mulford and B. Edmunds (Eds.) Successful school principalship in Tasmania. Launceston, Tasmania: Faculty of Education, University of Tasmania.

Neufield, G \& Roper, T. F., (2003). Sessional Paper No. 1 of 2005 on A policy Framework for Education, Training and Research. Nairobi: Government Printers.

Nwanna, P. L (2017).. Challenges and opportunities for quality assurance of cross border higher education in East Africa, In Ssempebwa, J., \& Neema-Abooki, P. (Eds), Innovating university education: Issues in contemporary African higher education. Kampala: Fountain Publishers. 
O'reilly, D. G., Ogawa, R. T., \& Chatman A. (1986). Leadership as an organization-wide phenomena: Its impact on school performance. Educational Administration Quarterly, 31(4), 564-588.

Ogawa, A. A (1995). Motivation and effective performance of academic staff in higher education: Case study of Adekunle Ajasin University, Ondo State, Nigeria). International Journal of Innovation and Research in Educational Sciences, 1(2), 157-163.

Okçu, V. (2011). Examination of the Relationship between School Administrators 'Leadership Styles and Teachers' Organizational Commitment and Levels of Mobbing, Gazi University Institute of Educational Sciences, Unpublished Doctoral Dissertation.

Peker, A. (2015). Investigation of the Relationships Between Adolescents' Aggression and Cyber Bullying Behaviors, EKEV Academy Journal, 19 (61), 323-336.

Pokharel, B. (2014). Principal as transformational leader: Getting to know new dimension in school leadership. American Journal of Social Science, 3(6), 61-66.

Purkey, S., \& Smith, M. (1983). Effective schools: A review. Elementary School Journal, 83, 427-452.

Recepoğlu, E. and Özdemir, S. (2013). The relationship between principals' instructional leadership behaviors and organizational health of the school, Educational Administration: Theory and Practice, 19 (4), 629-664.

Serin, K. (2011). The Relationship Between Instructional Leadership and Organizational Commitment in Primary Education Institutions. Unpublished Master's Thesis, Institute of Educational Sciences, Gazi University, Ankara, Turkey.

Sezer, Ş., Akan, D., \& Ada, Ş. (2014). Evaluation of Secondary Education Administrators' Levels of Performing Instructional Leadership Roles in Terms of Some Variables, Journal of Education and Training Research, 3 (1), 230- 249.

Short, B., \& Spencer, H. (1990). Revised models and conceptualization of successful school principalship in Tasmania. In B. Mulford and B. Edmunds (Eds.) Successful school principalship in Tasmania. Launceston, Tasmania: Faculty of Education, University of Tasmania

Silins, H. (1994). The relationship between transformational and transactional leadership and school improvement outcomes. School Effectiveness and School Improvement, 5(3) 272-298.

Şişman, M. (1997). Training of future leaders and leadership in education. Leadership Symposium in the 21st Century. Istanbul: D.H.O. Publications.

Şişman, M. (2012). Instructional leadership, Ankara, 4th edition, Pegem Akademi Publications.

Sky, N. (2004). Levels of Primary School Principals' Performing Instructional Leadership Roles and the Factors Limiting These Roles. Unpublished Doctoral Dissertation, Institute of Social Sciences, Hacettepe University, Ankara, Turkey.

Soder, S. B. (1987). Mbarara University research training initiative: a spin-off of the medical education partnership initiative in Uganda. Advances in Medical Education and Practice, 8, 527-533.

Southworth , A.J.. (2002). Shared leadership in higher education: Important lessons from research and practice. Washington, DC: American Council on Education.

Spillane, J. (2006). Distributed leadership, San Francisco: Jossey-Bass

Symonds, D. (2003). The research and rhetoric on teacher certification: A response to "Teacher certification reconsidered." Educational Policy Analysis Archives, 10 (36). 
Terzi, A. R. ve Kurt, T. (2005). The organizational effects of primary school principals' managerial behaviors effect on commitment, National Education Journal, 166, 98-111.

Thakur, D.N. \& Thakur, D. (2004). Educational Planning and Administration. $2^{\text {nd }}$ edition

UNESCO. 2004. Effects of Leaner; variable on Academic performance and Adjustment of Junior Students: Counselling Implication for UBE programme. Counselling Association of Nigeria. Conference August 2007.

Van de Grift, W. (1989). Self-perceptions of educational leadership and mean pupil achievements. In D., Reynolds, B.P.M., Creemers, \& T., Peters (Eds.), School effectiveness and improvement. Cardiff/Groningen: School of Education/RION (pp. 227242).

Villanova, R., Gauthier, W., Proctor, P., \& Shoemaker, J. (1981). The Connecticut school effectiveness questionnaire. Hartford, CT: Bureau of School Improvement, Connecticut State Department of Education.

Wango G. A. (2009). Cultivating leadership in schools: Connecting people, purpose, and practice. New York: Teachers College Press.

Whitterker, K. (1997). Job satisfaction of university academics: Perspectives from Uganda. Higher Education, 50(1), 33-56.

York-Barr, J., \& Duke, K. (2004). What do we know about teacher leadership: Findings from two decades of scholarship. Review of Educational Research, 24(3), 255-316.

Yüce, S. (2010). Investigation of the Relationship Between the Instructional Leadership Behavior of Primary School Principals and the Organizational Commitment of Teachers. Unpublished Master's Thesis, Institute of Educational Sciences, Gazi University, Ankara, Turkey.

Zepeda \& Sally (2003) The Principal as an Instructional Leader: a handbook of Supervision, Eye on Education, New York. 